\title{
Purification of xylanase produced by Bacillus pumilus
}

\author{
Ranganathan Kapilan ${ }^{1}$ and Vasanthy Arasaratnam ${ }^{2 *}$ \\ ${ }^{1}$ Department of Botany, Faculty of Science, University of Jaffna, Jaffna. \\ ${ }^{2}$ Department of Biochemistry, Faculty of Medicine, University of Jaffna, Adiyapatham Road, Kokuvil West, Kokuvil.
}

\begin{abstract}
This study was aimed at purifying xylanase produced by Bacillus pumilus. The spent medium contained 27.9 $\mathrm{UmL}^{-1}$ xylanase activity and $1.5 \mathrm{mgmL}^{-1}$ protein. The highest specific activity (33.7 $\mathrm{Umg}^{-1}$ protein) was achieved with $50 \%$ $\left(\mathrm{NH}_{4}\right)_{2} \mathrm{SO}_{4}$ saturation and the xylanase recovery was $94.8 \%$. The dialyzed and DEAE-Sepharose purified enzyme showed 6.7 -fold increase in specific activity with a yield of $84.2 \%$. Molecular weight of the purified xylanase was $55.4 \mathrm{KDa}$. Thus B. pumilus xylanase can be purified by precipitating with 50 $\%\left(\mathrm{NH}_{4}\right)_{2} \mathrm{SO}_{4}$ saturation and DEAE-Sepharose ion exchange chromatography.
\end{abstract}

Keywords: Ammonium sulphate saturation, DEAE-Sepharose, dialysis, purification fold, specific activity.

\section{INTRODUCTION}

Xylanase deconstructs xylan into xylose (Nakamura et al., 1995). Many bacterial and fungal species can produce xylanase. Xylanases, which are active under alkaline and thermostable conditions are widely used in paper industry to bleach craft pulp and to increase the brightness (Zamost et al., 1991), to improve the digestibility of animal feed and to clarify juices in food industry (Nakamura et al., 1995). As the xylanases produced by different microorganisms vary in physiochemical characteristics (McCarthy, 1987), it is important to optimize the procedures adopted for the purification of xylanases of different microbial sources. Usually in the purification studies more than one method is adopted. Thus the purification of thermostable alkaline xylanase (Kapilan \& Arasaratnam, 2011a) produced by Bacillus pumilus (Kapilan \& Arasaratnam, 2010) was studied.

The enzymes are purified using different techniques such as partitioning (Yang et al., 2008); anion exchange adsorption; hydrophobic interaction chromatography (Breccia et al., 1998); $\left(\mathrm{NH}_{4}\right)_{2} \mathrm{SO}_{4}$ precipitation (Breccia et al., 1998; Gessesse \& Mamo, 1998; Bataillan et al., 2000); anion exchange chromatography; gel filtration and affinity chromatography (Bataillan et al., 2000); gel filtration and ion-exchange chromatography (Christalopoulos et al., 1996; Gessesse \& Mamo, 1998; Cepeljnik et al., 2001); precipitation with Eudrgit (Gupta et al., 1994) and three phase portioning (Sharma \& Gupta, 2002). As most of the previous studies have used more than two methods for the purification of xylanase from crude culture filtrates, experiments were conducted to find a rapid method for the purification of xylanase from B. pumilus (Kapilan \& Arasaratnam, 2011b).

\section{METHODS AND MATERIALS}

DEAE-Sepharose (diethyl amino ethyl Sepharose fast flow) was purchased from Pharmacia, Uppsala, Sweden. All the other chemicals used were from standard sources. Xylanase was produced by solid state fermentation of Bacillus pumillus (Kapilan \& Arasaratnam, 2010; $2011 \mathrm{~b}$ ). The spent medium was centrifuged at $3000 \mathrm{rpm}$ for $30 \mathrm{~min}$ and the supernatant was used for purification studies.

The xylanase activity was measured in terms of reducing sugar produced by its action on xylan (Kapilan \& Arasaratnam, 2010). Protein concentration was determined by Lowry's method (Lowry et al., 1951). One unit of xylanase activity is defined as the amount of enzyme that produces $1 \mu$ mole of reducing sugar in $1 \mathrm{~min}$ at $\mathrm{pH} 9.0$ and $60{ }^{\circ} \mathrm{C}$ with $20 \mathrm{gL}^{-1}$ of xylan.

Solid $\left(\mathrm{NH}_{4}\right)_{2} \mathrm{SO}_{4}$ was added to crude xylanase to bring different saturation values (Dawson et al., 1969), mixed for $2 \mathrm{hrs}$, allowed to settle, and centrifuged (8000 rpm at $4{ }^{\circ} \mathrm{C}, 30 \mathrm{~min}$ ). The precipitate was dissolved 
in distilled water and dialyzed overnight against distilled water. The xylanase activity and the protein content were measured.

DEAE-Sepharose was activated with $0.1 \mathrm{M} \mathrm{NaOH}$ and $\mathrm{HCl}$, and equilibrated with $0.01 \mathrm{M}$ Tris buffer $(\mathrm{pH}$ 8.0 ). The precipitated and dialyzed xylanase was added and mixed (100 rpm, $30 \mathrm{~min})$ at room temperature. The unbound enzyme was removed by centrifugation and the residue was re-suspended in Tris buffer $(\mathrm{pH}$ 8.0) to wash the unbound enzyme. The DEAE-Sepharose bound xylanase was eluted with different concentrations of sodium chloride. The bound and unbound xylanase activities and protein contents were measured.

Xylanase, which was precipitated with $\left(\mathrm{NH}_{4}\right)_{2} \mathrm{SO}_{4}$ and dialyzed overnight, was loaded to the activated and equilibrated DEAE-Sepharose (with 0.01 M Tris buffer, $\mathrm{pH} 8.0$ ) containing column $[7 \times 1 \mathrm{~cm}$ (bed volume $5.5 \mathrm{~mL})]$. Unbound proteins were removed with 10 bed volumes of $0.01 \mathrm{M}$ Tris buffer $(\mathrm{pH} 8.0)$ at a flow rate of $1 \mathrm{mLmin}^{-1}$. Bound proteins were eluted with optimized $\mathrm{NaCl}-0.01 \mathrm{M}$ Tris buffer, $(\mathrm{pH} 8.0)$ at a flow rate of $1 \mathrm{mLmin}^{-1}$. The xylanase activity and the protein contents were analyzed. The pooled purified xylanase sample was subjected to SDS acrylamide gel electrophoresis (Koseki et al., 1997) and molecular weight of the purified xylanase was calculated (Weber \& Osborn, 1969).

\section{RESULTS AND DISCUSSION}

The culture supernatant used for the purification contained $27.9 \mathrm{UmL}^{-1}$ xylanase activity and $1.5 \mathrm{mgmL}^{-1}$ protein. The precipitation of protein increased with the $\left(\mathrm{NH}_{4}\right)_{2} \mathrm{SO}_{4}$ saturation percentage while the enzyme activity increased up to $50 \%$ of $\left(\mathrm{NH}_{4}\right)_{2} \mathrm{SO}_{4}\left(33.7 \mathrm{Umg}^{-1}\right.$ protein) (Table 1) and the specific activity of xylanase increased by 1.8 times.

The enzyme $(2 \mathrm{~mL})$ having $46.8 \mathrm{UmL}^{-1}$ of xylanase activity and $1.4 \mathrm{mgmL}^{-1}$ protein was used for the purification. When the concentration of $\mathrm{NaCl}$ in Tris buffer varied, the xylanase activity and protein eluted increased up to $0.8 \mathrm{M} \mathrm{NaCl}(80 \%)$ (Table 1) with the recovery of protein up to $32 \%$. Therefore $0.8 \mathrm{M} \mathrm{NaCl}$ was selected.

The $\left(\mathrm{NH}_{4}\right)_{2} \mathrm{SO}_{4}$ precipitated sample $(2 \mathrm{~mL}$ - specific activity $33.2 \mathrm{Umg}^{-1}$, total protein content $4.7 \mathrm{mg}$, total xylanase activity $156.8 \mathrm{U}$ ) was loaded to the DEAESepharose column. Fractions from 5 to 9 contained the proteins without any xylanase activity (Figure 1). The fractions from 16 to 22 ( 7 fractions) contained proteins with xylanase activity, fraction 18 having the highest. Pooled fraction (16 to 22) showed $18.9 \mathrm{UmL}^{-1}$ xylanase activity with $0.09 \mathrm{mgmL}^{-1}$ protein. Thus the specific activity of xylanase was increased from 33.2 to 223.7 $\mathrm{Umg}^{-1}$ protein, which was 6.7 fold higher than that of the crude xylanase with $84.2 \%$ yield (Table 2 ).

The distance travelled by the molecular markers and purified xylanase were measured when the purified xylanase was subjected to gel electrophoretic separation (Figure 2) and the molecular weight of the purified xylanase was estimated to be $55.4 \mathrm{KDa}$. The molecular weight of this xylanase closely resembled that of Micrococcus sp. AR-135 xylanase (Gessesse \& Mamo, 1999) while those of $B$. thermantarcticus (Bataillan et al., 2000) and B. amyloliquefaciens (Breccia et al., 1997) had lower values, and that of Bacillus sp. strain SPS - O had a higher value (Bataillan et al., 2000).

Table 1: Effect of ammonium sulphate saturation percentage on the precipitation of xylanase from Bacillus pumilus and the effect of $\mathrm{NaCl}$ concentration on the elution of xylanase bound to DEAE-Sepharose

\begin{tabular}{ccccccc}
\hline $\begin{array}{c}\left(\mathrm{NH}_{4}\right)_{2} \mathrm{SO}_{4} \\
(\%)\end{array}$ & $\begin{array}{c}\text { Xylanase } \\
\text { activity } \\
\left(\mathrm{UmL}^{-1}\right)\end{array}$ & $\begin{array}{c}\text { Protein } \\
\left(\mathrm{mgmL}^{-1}\right)\end{array}$ & $\begin{array}{c}\text { Specific activity } \\
\left(\mathrm{Umg}^{-1} \text { protein }\right)\end{array}$ & $\begin{array}{c}\mathrm{NaCl} \\
(\mathrm{M})\end{array}$ & $\begin{array}{c}\text { Xylanase } \\
\text { activity } \\
\text { eluted (\%) }\end{array}$ & $\begin{array}{c}\text { Protein } \\
\text { eluted (\%) }\end{array}$ \\
\hline & 10.0 & 0.54 & 18.7 & 0.0 & 5.0 & 10.0 \\
10 & 19.8 & 0.91 & 21.8 & 0.4 & 60.0 & 28.0 \\
20 & 29.4 & 1.02 & 28.9 & 0.8 & 80.0 & 32.0 \\
30 & 33.3 & 1.10 & 30.3 & 1.2 & 80.0 & 35.0 \\
40 & 46.8 & 1.39 & 33.7 & 1.6 & 80.0 & 35.5 \\
50 & 45.0 & 1.78 & 25.3 & 2.0 & 80.0 & 36.0 \\
60 & 43.8 & 2.65 & 16.6 & - & - & - \\
70 & & & & & & \\
\hline
\end{tabular}




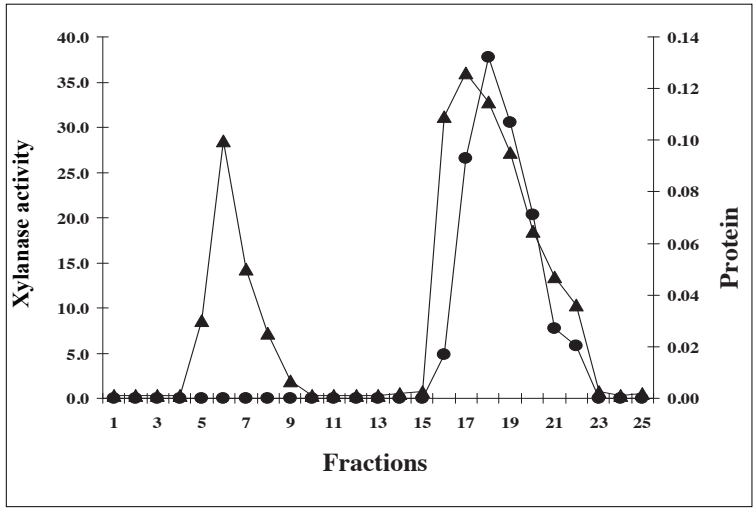

Figure 1: Separation of xylanase precipitated with $50 \%$ ammonium sulphate and DEAE-Sepharose

$(\bullet)$ xylanase activity $\left(\mathrm{UmL}^{-1}\right)$ and $(\boldsymbol{\Delta})$ protein $(\mathrm{mg})$ eluted with $0.8 \mathrm{M} \mathrm{NaCl}-0.01 \mathrm{M}$ Tris buffer (pH 8.0) at a flow rate of $1 \mathrm{mLmin}^{-1}$

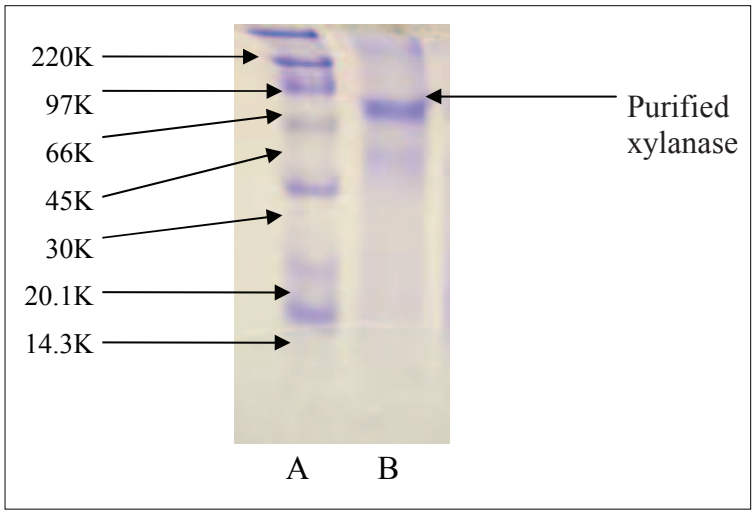

Figure 2: SDS-PAGE pattern of purified xylanase from Bacillus pumilus

Lane A: marker proteins; lane B: purified xylanase sample

Table 2: Purification of xylanase from Bacillus pumilus by precipitation with $50 \%\left(\mathrm{NH}_{4}\right)_{2} \mathrm{SO}_{4}$ saturation and DEAE-Sepharose chromatography

\begin{tabular}{lcccc}
\hline Purification step & $\begin{array}{c}\text { Total activity } \\
(\mathrm{U})\end{array}$ & $\begin{array}{c}\text { Total protein } \\
(\mathrm{mg})\end{array}$ & $\begin{array}{c}\text { Purification } \\
\text { fold }\end{array}$ & $\begin{array}{c}\text { Recovery } \\
(\%)\end{array}$ \\
\hline Crude $(6 \mathrm{~mL})$ & 165.5 & 8.96 & 1.0 & 100 \\
$\left(\mathrm{NH}_{4}\right)_{2} \mathrm{SO}_{4} 50 \%$ & 156.8 & 4.73 & 1.8 & 94.8 \\
Saturation $(2 \mathrm{~mL})$ & & & & \\
DEAE-Sepharose & 132.0 & 0.59 & 6.7 & 84.2 \\
\hline
\end{tabular}

\section{CONCLUSION}

The specific activity of the crude (xylanase enzyme 18.5 $\mathrm{Umg}^{-1}$ protein) was increased to $33.2 \mathrm{Umg}^{-1}$ protein by $\left(\mathrm{NH}_{4}\right)_{2} \mathrm{SO}_{4}$ precipitation. Further purification by ion exchange chromatography using DEAE-Sepharose increased the specific activity to $223.7 \mathrm{Umg}^{-1}$ protein. The molecular weight of the purified xylanase of Bacillus pumillus was $55.4 \mathrm{KDa}$.

\section{Acknowledgement}

The authors acknowledge Sida/SAREC and International Programme in the Chemical Sciences (IPICS), Sweden for financial support.

\section{REFERENCES}

1. Bataillan M., Cardinali A.P.N., Castillon N. \& Duchiron F. (2000). Purification and characterization of a moderately thermostable xylanase from Bacillus sp. strain SPS-O.
Enzyme and Microbial Technology 26: 187 - 192.

2. Breccia J.D., Sineriz F., Baigori M.D., Castro G.R. \& Hatti-Kaul R. (1998). Purification and characterization of a thermostable xylanase from Bacillus amylolicquefaciens. Enzyme and Microbial Technology 22: 422 - 449.

3. Cepeljnik T., Zorec M., Nekrep F.V. \& Logar R.M. (2001). Isolation of endoxylanases from anaerobic bacterium Butyrivibrio sp. strain M25 is possible by anion exchange chromatography on CIM DEAE - 8 monolytytithic column. Acta Chimica Slovenica 48: 401 - 408.

4. Christalcopoulos P., Nerinck W., Kekos D., Macris B. \& Claeyssens M. (1996). Purification and characterization of two low molecular mass alkaline xylanases from Fusarium oxysporum F3. Journal of Biotechnology 51(2): 181 189.

5. Dawson R.M.C., Elliot D.C., Elliot W.H. \& Jones K.M. (1969). Data for Biochemical Research (eds. R.M.C. Dawson \& D.C. Elliot), $2^{\text {nd }}$ edition, pp. $120-121$. Oxford University Press, London, UK.

6. Gessesse A. \& Mamo G. (1998). Purification and characterization of an alkaline xylanase from alkalophilic Micrococcus sp. AR-135. Journal of Industrial Microbiology and Biotechnology 20: 210 - 214. DOI: http://dx.doi.org/10.1038/sj.jim.2900503 
7. Gessesse A. \& Mamo G. (1999). High-level xylanase production by Micrococcus sp. AR-135. Enzyme and Microbial Technology 25: $68-72$.

8. Gupta M.N., Guoqiang D., Kaul R. \& Mattiasson B. (1994). Purification of xylanase from Trichoderma viridae by precipitation with an anionic polymer eudragit $\mathrm{S} 100$. Biotechnology Technology 8: 117 - 122. DOI: http://dx.doi.org/10.1007/BF00152851

9. Kapilan R. \& Arasaratnam V. (2010). A novel Bacillus pumilus strain for alkaline xylanase production at and above $40{ }^{\circ} \mathrm{C}$. Malaysian Journal of Biochemistry and Molecular Biology 18: 7 - 15 .

10. Kapilan R. \& Arasaratnam V. (2011a). Comparison of the kinetic properties of crude and purified xylanase from Bacillus pumilus with commercial xylanase from Aspergillus niger. Vingnam Journal of Science 10(1): $1-6$.

11. Kapilan R. \& Arasaratnam V. (2011b). Paddy husk as support for solid state fermentation to produce xylanase from Bacillus pumilus. Rice Science 18(1): 36 - 45.

12. Koseki T., Furuse S., Ivvana K., Sakai H. \& Matsuzawa H. (1997). An Aspergillus awamori acetylesterase: purification of the enzyme and cloning and sequencing of the gene. Biochemical Journal 326: 485 - 490.

13. Lowry O.H., Rosenburg N.J., Farr A.L. \& Randall R.J. (1951). Protein measurement with the folin phenol reagent. Journal of Biological Chemistry 193: 265 - 275.
14. Mc Carthy A.J. (1987). Lignocellulose- degrading actinomycetes. FEMS Microbiology Letters 46 (2): $145-163$.

15. Nakamura S., IshiguroY., Nakai R., Wakabayashi K., Aono R. \& Horikoshi K. (1995). Purification and characterization of a thermophilic alkaline xylanase from thermoalkaliphilic Bacillus sp. strain TAR-1. Journal of Molecular Catalysts and Biocatalysts 1: $7-15$.

16. Sharma A. \& Gupta M.N. (2002). Macroaffinity ligandfacilitated three-phase partitioning (MLFTPP) for purification of xylanase. Biotechnology and Bioengineering 80: $228-232$.

DOI: http://dx.doi.org/10.1002/bit.10364

17. Weber K. \& Osborn M. (1969). The reliability of molecular weight determinations by dodecyl sulfate-polyacrylamide gel electrophoresis. Journal of Biological Chemistry 244: $4406-4412$.

18. Yang S., Jiang J. \& Li L. (2008). Partition and purification of thermostable xylanase produced by Paecilomyces thermophilia in solid-state fermentation using aqueous two-phase system. Process Biochemistry 43(1): $56-61$.

19. Zamost B.L., Nielsen H.K. \& Starnes R.L. (1991). Thermostable enzymes for industrial applications. Journal of Industrial Microbiology 8: $71-82$. DOI: http://dx.doi.org/10.1007/BF01578757 